\title{
Die kerklike hantering van eietydse transformasieprosesse deur die bedryf van ' $n$ arbeidspsigologiese nywerheidsbedieningsmodel
}

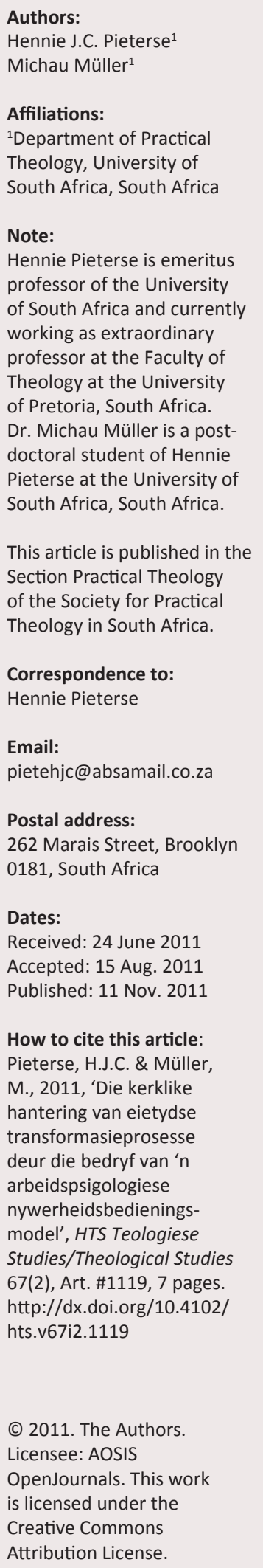

Authors:

Hennie J.C. Pieterse

Affiliations:

${ }^{1}$ Department of Practica

Theology, University of

Note: professor of the University working as extraordinary professor at the Faculty of Theology at the University Pieterse at the University of

This article is published in the Section Practical Theology of the Society for Practical

Correspondence to:

Email:

Postal address:

262 Marais Street, Brooklyn

Dates:

Received: 24 June 2011

Accepted: 15 Aug. 2011

How to cite this article: Pieterse, H.J.C. \& Müller M., 2011, 'Die kerklike transformasieprosesse deur die bedryf van ' $n$ arbeidspsigologiese nywerheidsbedieningsmodel', HTS Teologiese Studies/Theological Studies hts.v67i2.1119

Attribution License.
The utilising of a Christain workpsychological industrial church mission to address the modern transformation processes

The church reacted unsatisfactoraly to both political and industrial change. This situation neccessitated the development of a workpsychological industrial mission. This model combines the different industrial mission models, the structure and system of Industrial Mission in South Africa (IMSA) and the German workpsychological approach. The main aim is self-development and self-actualisation. The implication of the model is through Scripture ministry with a special focus on social ethics and a worktheology. The second leg is pastorale care which implements the employee assistant programs (EAP) of companies and adresses the work, personal and environmental problems of all gender, religion and cultural groups from a Christian perspective. The failure of the church to utilise the industrial mission to the full results in a loss for the church's ministry during transformation.

\section{Inleiding}

In 'n vorige artikel (Müller \& Pieterse 2008:140-161) is aangetoon dat die hoofdryfkragte agter eietydse transformasie industrieel en polities van aard is. Die industriële invloede realiseer vanuit die skep van 'n nuwe ekonomiese dispensasie en globalisering. Die resultaat is wêreldwye veranderinge en enorme sosio-ekonomiese uitdagings. Polities speel politieke bevryding, en veral die vestiging van ' $n$ Suid-Afrikaanse demokratiese bestel, die grootste rol. Beide dryfkragte oefen invloede buite en binne die kerk uit.

In die tweede artikel oor hierdie onderwerp (Müller \& Pieterse 2010) is die reaksie van die kerk op hierdie dryfkragte uitgespel. Met die politieke hantering is ' $n$ gelokaliseerde teologie met ' $n$ kontekstuele inhoud geskep waarin politieke teologie ' $n$ oorheersende rol speel. Kerkvernuwing poog weer om die industrieële opset te verwerk. In die proses is ' $n$ nuwe visie en missie vir nywerheidsbediening geformuleer en ' $n$ interkerkllike organisasie te wete die Industrial Mission of South Africa (Industrial Ministry South Africa 2001, 2002, 2003) gestig. Vanuit hierdie proses is ' $n$ arbeidpsigologiese bedieningsmodel geïnisieer wat in hierdie laaste artikel omskryf word.

\section{Saamgestelde bedieningsinhoud}

Die voorgestelde arbeidpsigologiese bedieningsmodel is vanuit die verskillende nywerheidsbedieningsmodelle, die bedieningsopset van die Industrial Ministry in South Africa (IMSA) en veral die Duitse arbeidpsigologiese metode saamgestel. Aandag aan al drie die komponente bied die nodige inhoud van die eiesoortige model.

\section{Toepassing van verskllende nywerheidsbedieningsmodelle}

Vanuit die wêreldwye kerklike betrokkenheid in die industrie is veral agt bruikbare nywerheidsbedieningsmodelle deur uiteenlopende Christelike kerkgenootskappe, oor dekades heen ontwerp (vgl. Koops 1965; Gostelow 1968; NIM 1970; Grenz 1972; McLeod 1975; Sodeman 1976; Wolfaardt 1989).

Met pastoral counselling is die fokus op persoonlike aandag aan die individu. Die grondoorsake van probleme (moreel, eties, godsdienstig) word onder begeleiding van die menslikehulpbronafdelings (MHB) konfidensieel in beradingsessies hanteer. Probleme buite werksverband word na die persoon se geïdentifiseerde leraar verwys. Die voordeel van die model is geestelike en pastorale bystand aan die individu in nood. Die nadeel is dat geen berading kan realiseer sonder aanmelding of verwysing nie. 
Die ministry of presence-model behels die rondbeweeg van nywerheidsbedieningspersoneel (NBP) op die produksievloere en werkskantore. Daarmee word direk met die individu binne sy spesifieke werksomgewing kontak gemaak en word gesprekke oor werksgerigte probleme gevoer. Die voordeel is direkte waarneming. Die nadeel is werksteuringe en daarom word die soort bediening gewoonlik met die eerste model gekombineer.

Die prophetic mission-model behels ' $n$ tweërlei diens in beide die nywerheid en kerk. In die nywerhede geskied Woordverkondiging en literatuurverspreiding tydens georganiseerde etenstyd biduurdienste. In die kerk word gemeentes, kerkrade, ringe en sinodes spesifiek oor die kerklike optredes in die nywerheidsomgewing toegelig. Die voordele is verkondiging en bevordering. Die nadele is die gebrek aan opvolging in en deur die kerk.

Die preventive ministry-model bou positiewe verhoudinge met alle werknemers, identifiseer probleme, klagtes en reaksies op onreëlmatighede en onregverdighede en ontlont spanninge tussen vakbonde en bestuur. Die voordele vir die nywerhede is konflik ontlonting en vir die kerk die aanbied van morele, etiese en geestelike waardes. Die nadele is die maak van keuses wat die evangelie kompromitteer.

Die evangelistic mission-model fokus op bekering waartydens mense direk, daadwerklik en planmatig vir Christus tydens Woordverkondiging, bekeringsgerigte pastoraat en Bybelstudies in die werkplek gewen word. Die voordele van die model is die uitbreiding van die koninkryk van God. Die nadele is die afhanklikheid van die topbestuur wat 'n Christelike fokus aanvaar of verwerp.

Met die public relation mission word ' $\mathrm{n}$ goeie beeld van ' $\mathrm{n}$ nywerheid gevestig, bevorder en onaangetas gehou. Deel van die funksies is konstante hospitaalbesoeke na ongelukke en die bywoning van begrafnis- en herdenkingsdienste waartydens die simpatie van die bestuur oorgedra word. Die voordele van die model is 'n direkte kerklike betrokkenheid tydens krisisgebeure. Die nadele is voorskrifte en verwagtinge waartydens die belange van die instansie in plaas van die kerk en die godsdiens voorkeur geniet.

Die model-action ministry behels die vestiging van 'n diensgroepspan bestaande onder andere uit predikante, sielkundiges, raadgewers en konsultante wat vanuit 'n interdissiplinêre fokus as 'n georganiseerde projekspan optree. Die hooffokus is sosiale probleme (o.a. drankmisbruik, dwelmgebruik, vigs) wat deur middel van interne berading en ook met verwysings na tersaaklike institute en versorgingsinrigtings hanteer word. Die voordele van die model is interdissiplinêre verbreding vir en 'n betrokkenheid in nywerheidsprobleme buite die bedieningsfeer van die kerk. Die nadele is die verlies aan ' $n$ godsdienstige fokus omdat ander eise, naas die evangeliese, aan die projekspan gestel word.
Die part-time ministry-model word bedryf deur lekearbeiders wat op 'n vrywillige en gereelde basis spesifiek geestelike funksies binne 'n nywerheid verrig. Die voordele is kostebesparing vir die kerk en nywerheid omdat die vrywilliger die dienste self subsideer. Die nadele is onreëlmatige dienslewering en die verdwyn van die funksie saam met die vrywilliger.

Die IMSA-bediening het reeds al hierdie modelle tot ' $n$ nuwe bruikbare formaat omgebou. Daarom behels die tweede komponent die integrering van die IMSA-bediening.

\section{Integrgrasie van Industrial Ministry in South Africa (IMSA)}

IMSA bied bestaande en gevestigde bedryfsomvange wat bruikbaar binne die nuwe bedieningsmodel aangewend word.

Die visie van IMSA word in die nuwe bedieningsmodel gehandhaaf:

Industrial Ministry... wants to emphasise and to live the Gospel's virtues in such a way that the Kingdom of God may be clearly established and built up in and around the world of work.

(Industrial Ministry South Africa 2001:4)

Hierdie visie word binne ' $n$ interkerklike, interdenominale en interkulturele nutsmaatskappy toegepas en wel sodanig dat die genoemde ekonomiese en politieke transformasieprosesse geakkomodeer kan word. Die gevestigde struktuur bied ook die nodige Christelike perspektief waarmee die spesifieke behoeftes en voorskrifte van die nywersheidsomgewing names die kerk hanteer word (Müller 2005:306-307).

Die eiesoortige kerklik-teologiese perspektief van IMSA word ook gehandhaaf (Müller 2005:300-301). Daarmee word Christelike geloofsdimensies in die werksituasie, stresvlakke, bestuursinhoude en algemeen menslike verhoudinge benut. Hierdie gevestigde bedieningsinhoude maak juis gebruik van die genoemde arbeidsbedieningsmodelle en handhaaf daarmee vyf bruikbare bedieningsaksente.

Eerstens geskied Christelike Woordverkondiging op 'n vaste basis, tye en plekke waartydens ' $n$ tydsgerigte boodskap met toepaslike literatuurverspreiding aangevul word. Daarmee word die prophetic mission-model bedryf.

Tweedens word die Employee Assistance Program (EAP)-projekte op 'n gereelde basis saam met menslike hulpbronne beplan en gesamentlik uitgevoer. Hierin word konflik ontlont deur interkulturele verhoudinge te verbeter, word die delikate vigspandemie met begrip en diskressie hanteer en word talle persooonlike en gesinsprobleme sodanig aangespreek dat minimum negatiwitiete in die werksomgewing realiseer. Daarmee word die genoemde model-action program, die ministry of presence-model en die preventive ministry-model toegepas.

Derdens benut opgeleide beraders die pastoral counsellingmetode deur uit te reik na 'the persons where they are, as they are' (Sodeman 1976:14). 
Vierdens pas IMSA die public relations-model toe deur besoeke aan gemeentes, ringe en kerklike vergaderings te bring. Die hoofaksent is egter die bevordering van IMSA en nie die vestiging van 'n gunstige beeld van maatskappye nie.

Laastens verplig onvoldoende fondse IMSA om die part-time ministry-model te implementeer. Daarmee word opgeleide vrywilligers binne 'n spesifieke werksomgewing ontplooi om veral die predikings- en pastoraatverwysings te behartig.

Met hierdie aktiwiteite is 'n bruikbare struktuur, funksies en interkerklike dimensie gevestig wat in die nuwe model geakkommodeer word. 'n Nuwe inset kom egter vanuit die inkorporering van die Duitse arbeidspigologiese-model na vore.

\section{Inkorporering van die Duitse arbeidspsigologiese- model}

In die Duitse arbeidpsigologiese-model gaan dit om interdissiplinêre samewerking tussen die kerk en alle ander mensgerigte wetenskappe. Die hoofmikpunt is die integrering van selfontwikkeling (Selbstentwicklung) en selfverwesentliking (Selbstverwirklichung) deur bedryfsielkundige prosesse binne die werksomgewing toe te pas (vgl. Schuler \& Stehle 1982; Hirth, Sattelberger \& Stiefel 1987; Erpenbeck \& Weinberg 1993; Hacker 1998; Freiling \& Sonntag 1999).

Die selfontwikkeling vestig 'n persoonlikheidsverdieping en wel deur die waarneming, verwerking, aanpassing en benutting van elke gebeure binne die persoonlike werksen samelewingsmilieu. Selfverwesentliking poog weer om 'n lewensproses van persoonlike selfuitlewing, die vestiging van ' $n$ eie persoonlike lewensstatuur (Lebensgestaltung) en korrekte persoonlike optredes te bereik. Daarmee word 'n bruikbare lewensinhoud en lewenstoekoms rondom gevestigde waardes en verantwoordelikhede binne alle werksverbande uitgeleef.

Die Duitse model word deur ses toepaslike elemente bedryf. 'n Tydsfokus verseker tydsgerigte optredes, die menslike aksent bevorder menswaardigheid, en die arbeidsinsette verdiep die selfwaarde vanuit ' $n$ sinvolle lewensbestaan. Deeglike beplanning begelei die beroepsgerigtheid, menslike verhoudingstrukture word hanteer en werkstabiliteit waarborg werkstevredenheid en werksuksesse (vgl. Hirth, Sattelberger \& Stiefel 1987).

Die sinkronisering van die gegewens vanuit die verskillende bedieningsmodelle, die IMSA bedieningsopset en die Duitse fokus vra om 'n spesifieke benadering.

\section{Benadering met die nuwe bedieningsmodel}

Enige nuwe Suid-Afrikaanse bedieningsmodel moet beide die genoemde ekonomiese asook politieke dryfkragte agter eietydse transformasie akkommodeer. Sodanige kerklike bediening vereis egter ' $n$ bepaalde teologiese perspektief en ' $n$ omskrewe fokus wat die inhoude van die betrokke kerklike optredes bepaal en rig.

\section{Gerigtheid vanuit teologiese perspektief}

'n Teologiese perspektief vestig ' $n$ teologiese teorie van waaruit ' $n$ bepaalde paradigma geformuleer, ' $n$ teologiese fokus geïdentifiseer en ' $n$ metodologiese vertrekpunt gehandhaaf word. Binne die nywerheidsomgewing word egter dikwels ' $n$ ander heilsboodskap as die evangelie gebring en daarom setel in hierdie leemte die geleentheid vir die kerk om koers aan 'n mondige maar soekende wêreld te gee. Vir die soort proses is 'n rigtinggewende teologie vanuit die evangelie juis nodig (Blauw s.j.:25-31) ten einde ' $n$ vorm van wêreldevangelisering te vestig (vgl. Sogaard 2004).

Die interdissiplinêre en empiriese gerigthede binne die nywerheidsomgewing vereis dat die wetenskaplikheid van die teologie gehandhaaf moet word. Daarmee word die metafisiese karakter van die evangelie nog steeds as ' $n$ eiesoortige rasionalitiet gehandhaaf, maar word kerklike wêreldbetrokkenheid ook as 'n geloofsdaad beklemtoon. Juis die soort gerigtheid verseker dat die nywerhede se aanwendbare bevindinge tot voordeel van die mens in sy totalitiet benut word. In wese word die teologiese strewe, om Woord, wêreld en mens verantwoordbaar in die nouste verhouding met mekaar te bring (Rossouw 1974:47-66), sinvol toegepas.

Hierdie toepassing van die teorie geskied vanuit 'n praktiesteologiese kommunikatiewe model. Daarmee word die nodige wêreldperspektief gevestig en word die kerklike inwaartse fokus na 'n uitwaartse gerigtheid verander. Tydens die proses is hierdie teorie die denkrefleksie oor die bepaalde bedieningsmodel asook die praktiese uitvoering daarvan. In die proses bied die Praktiese Teologie veral die normatiewe Christelike beginsels wat die kerk kan begelei om die eietydse transformasiegebeure tot uitbreiding van die koninkryk en tot voordeel van die gemeentelike bediening te hanteer (vgl. Pieterse 1993).

\section{Daarvoor is 'n omskrewe fokus noodsaaklik.}

\section{Aanwending van 'n omskrewe fokus}

Die model fokus op die twee mees bruikbare IMSA-funksies, te wete Woordverkondiging en pastoraat. ' $n$ Eiesoortige teologiese faset word egter tot beide toegevoeg.

Met die Woordverkondiging word op 'n sosiaal-etiese dimensie en ' $n$ sinvolle arbeidsteologie gekonsentreer. Daarmee word 'n bestaande nywerheidsbehoefte aangespreek en benutbare teologiese insette aangewend. Die beradingsfokus geskied weer binne 'n Christelike pastoraat met inagneming van die selfontwikkeling- en selfverwesentlikingelemente van die Duitse model. In die proses word die pastoraat buite die gemeenteverband aangevul. 
Met beide hierdie elemente gaan dit egter nog steeds om ' $n$ Woordgebeure waarin die vestiging, handhawing en uitbouing van die koninkryk van God 'n kerklik-teologiese fondament vestig en handhaaf (vgl. Industrial Ministry South Africa 2003).

\section{Toepassing van die model}

Omdat van die grootste transformasiegebeure binne die werksverbande realiseer, geskied die toepassing van die model binne die werkplek. Tydens etensuurdienste, -bidure en -bybelstudies word 'n Christelike sosiaal-etiese lewensinhoud en 'n sinvolle werksteologie daadwerklik verkondig.

\section{Sosiaal-etiese inhoude}

Binne nywerhede speel etiese inhoude ' $n$ belangrike rol (vgl. Bowie 1992). In die proses word maatskappykritiek benut om juis die resultate van globalisering en die verskillende sosiaal-etiese gedragspatrone te analiseer. Die hoofmikpunt is egter die vestiging van gesonde werksverbande terwille van finansiële oorlewing (vgl. Oosthuizen, Coetzee, De Crunchy, Hofmeyer \& Lategan 1985). Talle misverstande oorheers daarmee dikwels die toneel en daarom word die interne en ekserne 'moral issues' konstant aangespreek (vgl. Natale 1983; eds. Snoeyenbos \& James 1983; eds. Hoffman \& Mooren 1984).

Intern gaan dit om die vestiging van korrekte etiese bedryfsbeginsels (Van Jaarsveld 1988:139-142), gesonde en gevestigde werksverhoudinge (vgl. Grigor 1985) en binne Suid-Afrika veral om die regte rassegesindhede (Bradnum, Niewoudt \& Tredoux 1993:204-211). Ekstern moet gesonde verhoudinge met die gemeenskap en die nodige sosiale verantwoordelikheid teenoor die gemeenskap gehandhaaf word (vgl. Dussell 1988; Esterhuyze 1990:115-126). Vanuit beide prosesse moet egter 'n regverdige sosiale lewensorde ontwikkel word (vgl. Benestad 1982).

Met die vestiging van die eiesoortige sosiaal-etiese aksente word 'n godsdienstige dimensie in die nywerhede se sekulêre beginsels ingedra. In die proses word God Drie-enig as die etiese bron aangetoon en wel omdat die inhoude daarvan in God se wil vervat en in Sy Woord en wet omskryf is. Daarmee word die omvattende social teaching van die Woord aangewend om alle eietydse morele probleme aan te spreek (Motlhabi 2000:1-18). Juis die Woordverkondiging vestig 'n nuwe verhouding met Christus waaruit alle etiese optredes konstant nuut gemaak word (vgl. Smedes 1971).

Die fokus op die kommunikatiewe handelingsteorie vestig die goddelike heil binne die totale leefwêreld van die individu (Pieterse 1993:5-19). Daarmee word die verhouding met God (vertikale relasie) en die verhouding met die self asook die medemens (horisontale relasie) binne 'n sosiokulturele etiese omgewing gevestig (Berkhof 1960:44-48). Die Duitse selfontwikkeling en selfverwesentliking gee verder die nodige dimensie aan die sin van arbeid omdat daarmee die noodsaaklike persoonlike verantwoordelikhede binne alle verhoudings- en werksetieke uitgebrei word (Hirth, Sattelberger \& Stiefel 1987:115-126). Hierby vind die evangelie aansluiting omdat die welsyn van die mens bevorder en daadwerklik verhoed dat 'de mens, niet misbruikt, verbruikt en daardoor onbruikbaar wordt' (Brunner 1967:79-82).

Met die bied van 'n geestelike dimensie aan die sosiaal-etiese inhoude word 'social conditions, evaluative norms and religous vision' sodanig gekombineer dat 'n nuwe siening oor die etiese omvange en die regte persoonlike hantering daarvan uitkulmineer (Winter 1968:4-15).

Hierdie proses word verder deur 'n sinvolle werksteologie uitgebou.

\section{Bruikbare werksteologie}

Korrekte insigte oor Christelike optredes binne werksverbande vra vir duidelike perspektiewe oor werk as sulks. Hierin is die eietydse werksproblematieke binne die industriële, politieke en kerklike omgewings van wesentlike belang.

Binne die industriële omgewing is die hantering van werksgeleenthede ' $n$ sentrale faset tydens die verwerking van die eietydse transformasiegebeure. Talle veranderinge bedreig juis werksomvange omdat die eensydige strategiese fokus op ekonomiese voortbestaan, die afskaling van werksgeleenthede en die ondermyning van werkswaardes skep. Die proses tas juis die rol en betekenis van werk aan (Bridges 1996:vii-xi; vgl. Rifkin 1996).

Binne die Suid-Afrikaanse verband het die politieke veranderinge wetgewing geïnisieer wat werksdiskriminasie en talle ongelykhede moes uitskakel. Regstellende aksie, asook die nuwe bedingingsmagte vir vakbonde, het egter nuwe kritiese werksleemtes geskep wat selfs werksgeleenthede vernietig het. In die proses is diskriminasie en ongelykhede in die arbeidsmark nie opgehef nie, maar slegs werksverskuiwings gevestig waarmee weereens alleenlik bevoorregte groepe ekonomies bevoordeel is (vgl. Barker \& Backer 1992). Daarmee is die waarde van werk ook verwar.

Binne die kerklike omgewing het die nuwe arbeidsopset werksverliese van lidmate meegebring wat gemeentes en leraarsposte negatief geraak het. ' $n$ Nuwe armoedevraagtsuk en hewige gesinsontwrigtinge is daarmee geskep wat ' $n$ totaal nuwe vorm van pastoraat vereis. Die kerk se magteloosheid om werksgeleenthede te skep, het ' $n$ andersoortige druk op die waarde van werk geplaas wat juis 'n duidelike Bybelse perspektief oor werk as sulks genoodsaak. Van daaruit kan Christelike beginsels die humanistiese, materialistiese en sekulêre bestuursbeginsel sodanig aanpas dat die transformering van 'the workplace for Christ' inderdaad kan realiseer (vgl. Nix 1997).

'n Teologie van werk is hiermee die gegewe kerklikteologiese antwoord. Sodanige teologie is reeds oor dekades 
heen ontwikkel waarin die noodsaaklikheid daarvan en die Bybelinhoude daarmee omvattend omskryf is (Müller 2005:356-359). IMSA het juis bevind dat lidmate behoefte het aan ' $\mathrm{n}$ werksteologie, te meer omdat hulle kerke weinig oor werk preek, skryf en bid. Die leemte realiseer in 'n tydperk waartydens kritiese werksprobleme menige werknemers en -gewers se lewens oorheers en selfs ontwrig (vgl. Industrial Ministry South Africa 2003).

'n Werksteologie hanteer juis die noodsaaklike aksente wat die eietydse mens wil hoor. Die werker wil weet dat God ook werk (vgl. Banks 1992) en vervolgens dat werk seën en nie vervloek nie (vgl. eds. Banks 1993). God is ook in die werksplek teenwoordig (vgl. Lawrence 1989) en daaarom kan Christelike waardesisteme (vgl. Tucker 1987; Preece 1995) en 'n gesonde gebedslewe (vgl. Green 1981) 'n geestelike dimensie aan alle vorme van werk verleen (vgl. Volf 1991).

Met 'n werksteologie word ook 'n Christelike beroepsfokus (vgl. Bernbaum \& Steer 1986) sodanig gevestig dat die Christen se getuienis orals invloed uitoefen (vgl. Symanowski 1966). Daarmee word beide goeie werksverhoudinge bevorder (vgl. Grigor 1985) en ook die regte verhouding tussen geloof en werk verseker. Beide realiseer omdat die valse indruk, naamlik dat God geen belang by die daaglikse werksfunkseis het nie, besweer word (MacKenzie 1997:178) en God se koningskap in die werk beklemtoon word (vgl. Lawrence 1989).

Die soort aksente vra egter dat ' $n$ praktiese fokus die roeping van die Christen in die werksplek, 'n teologiese fokus die Bybelse inhoude van werk en die liturgiese fokus, die noodsaaklike verhouding tussen geloof en werk sal vestig. Die pastorale fokus hanteer alle medemenslike behoeftes, ongesonde werksverhoudinge en besweer daarmee werkskonflik (Müller 2005:356-359).

Hierdie soort werksteologie verbreed die Woordverkondiging en verseker daarmee dat kerklosses en kerkloses die evangelie buite die gewone gemeenteverbande, maar nie los van die koninkryksverbande nie, sal hoor (Sherman \& Hendricks 1987:240).

Hierdie soort bedieningsverbreding word verder deur 'n Christelike arbeidspsigologiese pastoraat bevorder.

\section{Christelike arbeidspsigologiese pastoraat}

IMSA het reeds omvattend bevind dat die Christelike pastoraat fenominale deurbrake binne die werksverbande verseker. Daarin speel pastorale diagnose en gevallewerk en veral ' $n$ Christelike onderbou 'n dinamiese rol (vgl. Van Rooyen \& Combrink 1985; Van der Merwe 1999:3). Proselietmakery word egter vermy omdat die Christelike terapeutiese fokus ook werknemers van ander geloofsdimensies dwarsdeur alle werkstragedies begelei (Sodeman 1976:15). Die pastoraat behels dus 'n vorm van wêreldevangelisasie (vgl. Sogaard 2004).
Die inskakeling by maatskappye se EAP-projekte verseker verder dat maksimum bystand aan werkers binne werks-, sosiale-, gesondheids- en gesinsverbande verleen word (IBC 1997:10-22). In alles word die geindustrialiseerde mens nie soseer vir die kerk nie, maar vir die koningkryk gewen omdat sy 'suppressed spirituallity and forgotten spiritual needs' tydens berading herontdek is (Casserley 1951:123).

Die nywerheidspastoraat skep egter talle eiesoortige dimensies. " $n$ Christelike pastoraat word aan alle gelowe en kulturele groepe bedien' (Müller 2005:360-361). Die kerklike bediening word ook verbreed omdat alle gevalle na hulle eie kerklike verbande terug verwys word. Juis hierdie proses verhoed dat die industriële lewensrolle nie in die gemeenteverbande ignoreer word nie (Bovet 1952:12-18). Die nywerhede vereis verder dat alle berading volgens die wetsbeginsels toegepas word (vgl. Allan 1997). Die interdissiplinêre fokus vra weer dat die pastoraat as diens aan God (teologiese aspek), as 'n verantwoordelikheid teenoor die samelewing (sosiologiese aspek) en as instandhouding van ware menswees (psigologiese aspek) bedien moet word (Marais 1969:223-245).

Met die spesifieke nuwe pastoraatmodel word Heitink (1998:127-149) se 'helen, bijstaan, begeleiden en verzoenen' as basis vir 'n Christelike pastoraat benut. Die 'helen' mobiliseer die geestelike, psigiese en fisiese vermoëns van die individu om volwaardig mens te word (die Duitse selfontwikkeling). Die 'begeleiding' inspireer mense om keuses te maak en van daaruit tot selfstandigheid te groei (die Duitse selfontwikkeling). Die 'bijstaan' behels die troos en bemoediging van mense tydens verlies, verdriet, pyn en lyding. Die 'verzoenen' hef die veroordeling van die naaste en die self op en verbind die soekende mens aan die verlossing van Christus. Hierby word 'n hoopdimensie gevoeg omdat die 'despair, apathy and shame' met 'trust, patience and modesty' vervang word (Capps 1995:98-162). In hoofsaak word die Christelike lewe as 'n lewe van ware vryheid, liefde, lydsaamheid en vreugde voorgehou (Brillenburg Wurth 1957:159-292). Verder word juis nuwe dimensies aan arbeid as sulks toegevoeg (Brillenburg Wurth 1957:232-289).

Hierdie genoemde toepassing van die gegewe model verseker dat die sosiaal-etiese dimensie die regte lewensbeginsels, die werksteologie, die waarde van werk en die arbeidspsigologiese pastoraat die nodige menslike begeleiding tot geestelike volwassenheid sal vestig.

Die uitvoering en toepassing daarvan binne die werksverbande is redelik ongekompliseerd, maar die kerklike aanvaarding daarvan is problematies.

\section{Aanvaarding van die model}

Nywerheidsbediening word in en deur die kerk verwaarloos. Daar is veelvuldige redes vir die onaanvaarbare opset (Müller 2005:413-417). Wat nou volg verskaf die redes vir hierdie stelling. 
Die kerk oorskat die rol, invloed en bydrae van die lidmaat binne die werksomgewing. Daarmee word die noodsaaklikheid vir nywerheidsbediening uitgerangeer omdat die kerk, volgens hierdie foutiewe persepsie, genoegsaam in die werksplek verteenwoordig is.

Verder meen die kerk dat die gewone gemeentelike bediening die veranderde tye kan hanteer. Transformasie het juis kerkvervreemding en selfs kerkverwerping geskep wat meebring dat die gewone gemeentelike bediening talle mense nie bereik nie. Nywerheidsbediening doen dit wel omdat direk na die mens in sy daaglikse werks- en lewensverbande uitgereik word.

Die kerk benut nie die kennis van sy lidmate nie. In die proses poog die kerk om 'n eie dimensie aan kritiese konsepte te gee terwyl kenners op die verskillende gebiede geamputeer word. Nywerheidsbediening figureer reeds binne die sekulêre omgewing en benut die interdissiplinêre opset tot die uitbreiding van die Godsryk.

Laastens meen die kerk verkeerdelik dat besluite oor nywerheidsbediening voldoende is om die nodige prosesse te aktiveer. Die soort bediening vra vir harde en georganiseerde werk wat konstant deur toegewyde en opgeleide dienspersoneel bedryf moet word. Die kerk se gebrekkige belangstelling in hierdie verlengstuk van die bediening bemoelik nie net die diensfunksies nie, maar vervreem ook die lidmate.

Hierdie gebreke benadeel die kerklike bediening en daarom word met ' $n$ toepaslike aanhaling afgesluit:

I simply argue that the cross should be raised at the enter of the marketplace as well as on the steeple of the church. I am recovering the claim that Jesus was not crucified in a cathedral between two candles, but on a cross between two thieves; on the town's garbage heap, at the crossroad so cosmopolitan that they had to write His title in Hebrew and Latin and Greek ... at the kind of place where cynics talk smut, and thieves curse, and soldiers gamble. Because that is where He died. And that is what He died for. And that is what He died about. And that is where churchmen ought to be and what churchmen ought to be about.

(McLeod 1975:1)

\section{Erkenning \\ Mededingende belange}

Die outeure verklaar dat hulle geen finansiële of persoonlike verbintenis het met enige party wat hulle nadelig kon beïnvloed in die skryf van hierdie artikel.

\section{Outeure se bydrae}

Beide outeure naamlik H.J.C. en M.M. het gelyke aandeel gehad in die skryf van hierdie artikel.

\section{Literatuurverwysings}

Allan, A., 1997, The law for psychotherapists and counsellors, Inter-Ed Publishers, Somerset West.
Banks, R.J., 1992, God the Worker, Albatross, Sutherland, Australia.

Banks, R.J. (ed.), 1993, Faith goes to work: Reflections from the marketplace, Alban Institute, Washinton, DC

Barker, F. \& Backer, W., 1992, Die Suid-Afrikaanse arbeidsmark: Kritiese aspekte vir 'n oorgangsfase, J.L. van Schaik, Pretoria.

Benestad, J.B., 1982, The pursuit of a just social order: Policy staements of the U.S. Catholic Bishops, 1966-1980, Ethics and Public Policy Centre, Johannesburg.

Berkhof, H., 1960, De mens onderweg, Boekencentrum, Den Haag.

Bernbaum, J.A. \& Steer, S.M., 1986, Why work? Careers and employment in biblical perspective, Baker Book House, Grand Rapids, MI.

Blauw, J., s.j., 'Verkondiging: Kans en koers', in C.A. van Peursen, C. Aalders \& Blauw, J., s.j. (reds.), Evangelieverkondiging in wereldperspektief, pp. 25-31, Kok, Kampen.

Bovet, Th., 1952, Practishe zielsorg, Boekencentrum, 'S-Gravenhage.

Bowie, N.E., 1982, Business ethics, Prentice Hall, Englewood Cliffs.

Bradnum, M., Nieuwoudt, J. \& Terdoux, C., 1993, 'Contact and the integration of racial attitudes in South Africa', South African Journal of Psychology, 23(4), 204-211.

Bridges, W., 1996, Jobshift: How to prosper in a workplace without jobs, Nicholas Brealey Publishing, London.

Brillenburg Wurth, G., 1957, Het Christelijk leven, 2 de druk, Kok, Kampen.

Brillenburg Wurth, G., 1961, Het Christelijk leven: In de maatschappij, Kok, Kampen.

Brunner, H.H., 1967, Kan men vandaag nog Christen zijn?, Boekencentrum, 'S-Gravenhage.

Capps, D., 1995, Agents of hope, Fortress Press, Minneapolis, MN.

Casserley, V.L., 1951, The retreat from Christianity in the modern world, Longmans, Green \& Co., London.

Dussell, E., 1988, Ethics and community, Orbis, Maryknoll, NY.

Erpenbeck, J. \& Weinberg, J., 1993, Menschenbild und Menschenbildung, Waxmann, Münster.

Esterhuyse, W.P., 1990, 'Die moreel-etiese verantwoordelikheid van die sakesektor', Instituut vir Reformatoriese Studies, 36, 115-126.

Freiling, E. \& Sonntag, K., 1999, Lehrbuch: Arbeitpsychologie, 2. Aufl., Hans Huber, Bern.

Gostelow, G.R., 1968, Ministry in industry, Hamilton, London.

Green, T., 1981, Darkness in the marketplace: The Christian at prayer in the world, Ave Maria Press, Notre Dame.

Grenz, C., 1972, Military industrial chaplaincy, U.S. Army, DARCOM, n.p.

Grigor, J.C., 1985, Work relationships, Bible Society, Swindon.

Hacker, W., 1998, Algemeine Arbeitspsychologie: Psychische Regulation von Arbeitstätigkeiten, Huber, Bern.

Heitink, G., 1998, Pastorale zorg: Theologie, differentiatie, praktijk, Kok, Kampen.

Hirth, R., Sattelberger, T. \& Stiefel, R. Th., 1987, Dein Weg zur Selbstverwirklichung, 2. Aufl., Presse-Druck, Augsburg.

Hoffman, W.M. \& Mooren, J.M. (eds.), 1984, Business ethics, McGraw Hill, New York, NY.

IBC 1997, IBC Conferences: Employee assistance programming and practitioner utilization, 1997, 19 March, IBC Publications, Johannesburg.

Industrial Ministry South Africa (IMSA), 2001, Operational Manual, n.p., Johannesburg.

Industrial Ministry South Africa (IMSA), 2002, Western and Southern Cape Annual Report, n.p., Johannesburg

Industrial Ministry South Africa (IMSA), 2003, Operational Manual 2003, n.p., Johannesburg

Koops, H., 1965, Industrial chaplaincy, Baker Books, Grand Rapids, MI.

Lawrence, B., 1989, The practice of the presence of God, Hodder and Stoughton, London.

Mackenzie, A., 1997, Faith at work: Vocation, the theology of work and the pastoral implications, University of Otago, Dunedin.

Marais, E.J., 1969, Pastorale sorg aan die mens in die bedryf, Christelike Uitgewersmaatskappy, Roodepoort.

McLeod, G., 1975, Program packet, Institute of Industrial and Commercial Ministries, Harrisonburg.

Mothlabi, M.B.G., 2000, Christian social ethics, University of South Africa, Pretoria.

Müller, M., 2005, 'Transformasie en die kerk: Die kerklike hantering van eietydse transformasie d.m.v. nywerheidsbediening', DTh-proefskrif, Departement Praktiese Teologie, Universiteit van Suid-Afrika, Pretoria.

Müller, M. \& Pieterse, H.J.C., 2008, 'Die hoofdryfkragte agter die eietydse transformasieprosesse soos dit die nywerheidsbediening beïnvloed', Praktiese Teologie in Suid-Afrika 23(2), 140-161.

Müller, M., \& Pieterse, H.J.C., 2010, 'Die kerklike stimulasie van eietydsetransform asieprosesse,en die geleentheid wat dít aan nywerheidsbediening bied', HTS Teologiese Studies/Theological Studies 66(2), 90-94.

Natale, S.M., 1983, Ethics and morals in business, REP Books, Chicago.

NIM 1970, 'One More Time Now: Do We Need Industrial Chaplaincies?', National Industrial Mission Briefs, December, 1-9. 
Nix, W., 1997, Transforming your workplace for Christ, Broadman \& Holman Publishers, Nashville, TN.

Oosthuizen, G.C., Coetzee, J.K., de Cruchy, J.W., Hofmeyer, J.H. \& Lategan, B.C., 1985 Religion, intergroup relations and social change in South Africa, HSRC, Pretoria.

Pieterse, H., 1993, Praktiese Teologie as kommunikatiewe handelingsteorie, RGN Uitgewers, Pretoria.

Preece, G., 1995, Changing work values: A Christian response, Acorn Press, Melbourne. Rifkin, J., 1996, The end of work, G.P. Putnams \& Sons, New York, NY.

Rossouw, H.W., 1974, 'Die nuwe teologiese hermeneutiek', in E.J. Smit, J.A.L. Taljaard, P.D. van der Walt \& S.C.W. Duvenhag (red.), Reformasie en Revolusie, pp. 47-66, Insitituut vir die Bevordering van Calvinisme, Potchefstroom.

Schuler, H. \& Stehle, W., 1982, Psychologie in Wirtschaft und Verwaltung, Poeschel, Stuttgart.

Sherman, D. \& Hendricks, W., 1987, Your work matters to God, Navpress, Colorado Springs, CO.

Smedes, L.B., 1971, 'All Things made new: A theology of man's union with Christ', Catholic Biblical Quaterly, 33, 15-24.

Snoeyenbos, M.A.R., \& James, H. (eds.), 1983, Business Ethics: Corporative values and society, Prometheus Books, Buffalo.
Sodeman, L., 1976, 'Business and Industrial Chaplaincy', National Institute of Business and Industrial Chaplains, June, 7-21.

Sogaard, V., 2004, 'Evangelizing our world: insights from global inquiry', Forum for World Evangelization, September, 3-5.

Symanowski, H., 1966, The Christian witness in an industrial society, Collins, London.

Tucker, G., 1987, The faith-work connection: A practical application of Christian values in the workplace, Anglican Book Centre, Toronto.

Van der Merwe, E.A., 1999, Pastorale betrokkenheid aan persone wat HIV+ is binne die arbeidsektor: ' $n$ Narratiewe benadering, Universiteit van Pretoria, Pretoria.

Van Jaarsveld, B., 1988, 'The theory and practice of business ethics in South Africa: A status report', Suid Afrikaanse Tydskrif vir Hoër Onderwys 2(1), 139-142.

Van Rooyen, I.J.J. \& Combrink, M.J., 1985, Gevallewerk, Academia, Pretoria.

Volf, M., 1991, Work in the Spirit: Toward a Theology of Work, Oxford University Press, New York.

Winter, G. (ed.), 1968, Introduction: Social ethics: Issues in ethics and society, SCM, London.

Wolfaardt, J.A., 1989, 'Reconcilitaion or conflict? Perspectives on industrial mission', Missionalia 17(1), 45-49. 